\title{
A Cor Canela e a Cidade Loira: um estudo de caso sobre a identidade dos povos originários no contexto urbanizado de Blumenau
}

\section{The Cinnamon Color and the Blonde City: a case study on the identity of people originated in Blumenau's urbanized context}

\author{
Flávia Roberta Busarello* \\ Jaison Hinkel ${ }^{* *}$
}

\begin{abstract}
Resumo: Esta pesquisa tem como tema a identidade indígena no contexto urbanizado da cidade de Blumenau. Para tanto foi feita uma entrevista em formato de História Oral e revisão bibliográfica de diversas obras no campo da psicologia e áreas afins. A pesquisa é pautada na história de Vaiká uma indígena que vem para Blumenau ainda criança e vivencia diversas situações excludentes. A identidade não é tida como um conceito estático, e sim em constante transformação e dialética com o meio, que neste caso se alterna entre a Terra Indígena Xokleng/Laklãnõ e a cidade de Blumenau. O movimento dialético de Vaiká ocasiona a criação e recriação de seu modo, que vivencia em Blumenau um contexto mediador mas também excludente. Diante de sua movimentação a Terra Indígena é reconhecida como acolhedora e o contexto urbanizado como excludente.
\end{abstract}

Palavras-chave: Identidade. Indígena. Blumenau

\begin{abstract}
This research has as its theme the indigenous identity in the context of the urbanized city of Blumenau, seeking to understand this movement. To do so it was made an oral history format interview and the review of several studies in the fields of psychology and related areas. The research is based on the story of an indigenous, named Vaiká, that goes to Blumenau as a child and experiences many diverse excluding situations. The identity is not taken as a pre-established concept but, in constant transformation and dialectic with the environment, which in this case alternates between the indigenous land Xokleng/Laklãnõ and the city of Blumenau. The dialectical movement of Vaiká causes the creation and recreation of her experience in Blumenau, a mediator but also excluding context. This movement causes the creation and re-creation of her identity, but nothing is ignored, because identity is in constant motion. Thus, the Indigenous land is recognized as comforting and Blumenau as exclusionary.
\end{abstract}

Keywords: Identity. Indigenous. Blumenau

\footnotetext{
"Mestranda do Programa de Pós-Graduação em Psicologia Social (PPGP-PUC/SP). Graduada em História e Psicologia (FURB). Foi bolsista da Coordenação de Aperfeiçoamento de Pessoal de Nível Superior do programa Observatório de Educação Escolar Indígena e participou do grupo de pesquisa EDUCOGITANS. Atualmente participa no Núcleo de Pesquisa Dialética Exclusão/Inclusão Social NEXIN. frbusarello@gmail.com.

"Doutorado em Psicologia (PPGP-UFSC). Mestre em Psicologia (PPGP-UFSC). Graduado em Psicologa (FURB). Professor do departamento de Psicologia da Universidade Regional de Blumenau. jaisonhinkel@yahoo.com.br
} 


\section{Introdução}

O meu interesse no estudo sobre identidade vem sendo construído desde minha primeira formação acadêmica no curso de História. No decorrer da graduação em Psicologia tive oportunidade de ser bolsista no grupo EDUCOGITANS ${ }^{1}$, coordenado pelo professor Ernesto Jacob Keim. Este grupo de pesquisa e extensão é vinculado ao Mestrado em Educação da Universidade Regional de Blumenau, denominado grupo de pesquisa Filosofia e Educação - EDUCOGITANS - onde se debatem temas como multiculturalismo, interculturalismo e identidade numa perspectiva de educação do Ser. Nas reuniões realizadas também discutíamos temas referentes à pesquisa financiada pela CAPES/FINEP, "Planejamento Pedagógico - Didático e Formação Intercultural de Professores para a Revitalização da Língua e da Cultura Xokleng nas Escolas Indígenas Laklãnõ e Bugio em Santa Catarina", vinculada ao Observatório Educação Escolar Indígena. Diante disto durante a participação no grupo EDUCOGITANS juntamente com o estudo das problemáticas da migração do povo originário, busquei compreender como se constrói a identidade do povo originário inserido neste contexto.

O tema a que este trabalho se direciona é a identidade do povo originário ${ }^{2}$ como desafio no contexto urbanizado é o tema a que esse trabalho se direciona, apresentando dois contextos: a Terra Indígena Xokleng/Laklãnõ e o contexto urbanizado de Blumenau.

A cidade mencionada localiza-se no Estado de Santa Catarina, na região do Vale do Itajaí, e foi fundada em 1850 pelo alemão Hermann Bruno Otto Blumenau. Este município possui uma ampla agenda cultural tipicamente alemã, com arquitetura e alimentação baseada nos hábitos da colonização germânica. Como uma das referências, a cidade possui a Oktoberfest, conhecida como a segunda maior festa do chopp do mundo. Neste contexto urbanizado o povo originário irá encontrar uma cultura e modos de

\footnotetext{
${ }^{1}$ Nome do grupo de pesquisa coordenado pelo Prof. Ernesto Jacob Keim do mestrado em Educação da Universidade Regional de Blumenau.

${ }^{2} \mathrm{O}$ Termo "originário" é utilizado nesta pesquisa para citar o povo indígena, sendo assim o termo "indígena" só será mencionado quando a entrevistada o fizer.
}

vida diferentes do seu meio habitual. Existe um discurso neste contexto o qual afirma que o habitual é o branco, colocando nas extremidades o povo originário.

Além disto, segundo a história regional, o povo originário é reconhecido como "bugres"3, aqueles que não auxiliaram na colonização. Enquanto o branco é visto como progresso, o construtor e colonizador da cidade de Blumenau e do Vale do Itajaí, enquanto isto, o povo originário é visto como intruso e anônimo.

Esta perspectiva afeta também a população não originária, que carrega desde a infância imagens estereotipada dos povos originários como seres que vestem tangas, cocares e plumas. Essa forma de comunicação instala uma representação que faz com que o imaginário se constitua com essa imagem simbólica. Com isso, a comunidade não indígena deixa de reconhecê-lo como um ser de direitos, com oportunidades iguais para desfrutar de tudo o que existe no contexto planetário. Essa inserção deste povo como ser que é integrante da totalidade humana, Ihe dá o direito de desfrutar de todos os avanços tecnológicos construídos pela humanidade, fazendo com que a realidade moderna se constitua como direito de uso de roupas, telefones, eletrodomésticos e eletrônicos, bem como, morar e conviver em cidades e não apenas em Terras Indígenas. ${ }^{4}$

Os povos originários, muito diferentes do que é anunciado pelo senso comum, se constituem num conjunto de pessoas que carregam conhecimentos e tradições muito distintas das brancas eurocêntricas convencionais, e essas desafiam o que está posto como certo e adequado pelo branco. Por conseguinte, esse povo também vivencia uma postura estereotipada, preconceituosa, que marca os diferentes que desafiam o que está posto.

Segundo a Fundação Nacional do Índio (FUNAI) existem 215 povos originários no Brasil com uma população aproximada de 345 mil indígenas, mas estas estimativas referem-se somente aos povos que vivem em Terras Indígenas. (ARAÚJO et al., 2006). Porém, existem outros

\footnotetext{
${ }^{3}$ Termo usado pelo branco para falar do povo originário.

${ }^{4}$ Estas reflexões foram feitas no grupo de pesquisa EDUCOGITANS entre o ano de 2010 e 2013, período em que a autora do artigo participou do grupo de pesquisa.
} 
milhares que vivem fora destas, bem como grupos isolados que não são considerados nesses dados, e nem por isso deixam de pertencer a esses povos, pois possuem cultura, tradição e linguagem entre outros aspectos singulares, que os caracterizam como tais.

Este artigo se refere especificamente a uma das Terras Indígenas de Santa Catarina, localizada na região do Vale do Itajaí, situado nos municípios de José Boiteux, Itaiópolis, Dr. Pedrinho e Victor Meireles, na qual vive o povo Xokleng/ Laklãnõ. Esta é constituída por oito aldeias nominadas como Pavão, Sede, Bugio, Toldo, Palmeirinha, Figueira, Coqueiro e Barragem.

Os povos originários da Terra Laklãnõ possuem cultura e tradição que se desdobram em hábitos diários, mitos e signos. Esta cultura é repassada entre as gerações através da oralidade e da língua Laklãnõ, portanto a memória é um dos maiores veículos de acesso ao conhecimento dos Xokleng/Laklãnõ. Além disso, no contexto da identidade destes, em relação aos povos e suas culturas, a memória se constitui numa forma de conservar informações e também é "[...] um elemento essencial do que se costuma chamar identidade, individual ou coletiva, cuja busca é uma das atividades fundamentais dos indivíduos e das sociedades de hoje." (LE GOFF, 1992. p. 476). Essas atribuições, muitas vezes de caráter simbólico, são vistas como gerais para todo um grupo, porém cada grupo social se singulariza perante o meio no qual está inserido e entre os sujeitos que compõe este contexto.

Um fato agravante que pesa contra a qualidade de vida desse povo é a construção da barragem situada na Terra Indígena Laklãnõ. Esta foi construída para proteger as cidades, do médio e baixo Vale do Itajaí, das enchentes, presentes nesta região. A construção desta barragem impossibilitou a agricultura e pesca anteriormente comuns naquela região. Diante dessa realidade, apesar da Terra Indígena proporcionar abrigo e espaço vital, algumas famílias, principalmente os jovens e adultos, migraram e continuam migrando para outras cidades procurando empregos e melhores condições de vida.

Nas proximidades da Terra Indígena existem outras cidades do Vale do Itajaí que possuem em sua maioria uma população constituída por descendentes de alemães, italianos e outros imigrantes europeus, os quais desenvolvem postura de matriz preconceituosa geradora de conflitos entre as diferentes etnias. Com isto, muitos membros da população branca estereotipam a figura povo originário e reproduzem essa postura aos filhos, netos e bisnetos como uma representação social ancorada em atos e estórias.

Na região do Vale do Itajaí a migração e vivências entre os brancos e povos originários, historicamente, têm gerado choque entre as identidades culturais e "no critério de pertença étnica a cultura é referida como uma das principais expressões desta diferença que age na manutenção e persistência das fronteiras" (MARKUS, 2006, p. 28). Tanto o choque cultural e o preconceito são frutos deste impasse identitário, mantido pelo discurso existente nesta região que reproduz uma normatização entre UM e o OUTRO, recriando margens e fronteiras.

Diante deste contexto este artigo procura compreender como se configura a identidade do ser originário que migra da Terra Indígena para o contexto urbano, neste caso Blumenau. É divido em duas partes a primeira que relata a cidade e suas práticas, e a segunda que traz a movimentação da entrevistada e como esta lida com a realidade do contexto urbanizado. Para tanto, foi feito um estudo de caso através de uma entrevista individual seguindo a metodologia da História Oral, pois

a memória por sua vez, como forma de conhecimento e como experiência, é um caminho possível para que sujeitos percorram os tempos de sua vida. [...] A memória é base construtora de identidades e solidificadora de consciências individuais e coletivas (DELGADO, 2006. p. 38)

A entrevista aconteceu nas dependências da Universidade Regional de Blumenau (FURB), em uma sala privada no Bloco $L$, com Vaika ${ }^{5}$ um sujeito do povo originário Xokleng/Laklãnõ, que vive na cidade de Blumenau desde os 12 anos e estuda Direito na Universidade Regional de Blumenau (FURB). No momento da pesquisa a entrevistada tinha 29 anos, foi casada com um branco e tem um filho. Mora distante da Universidade, e no momento da entrevista se encontrava desempregada. No entanto,

\footnotetext{
${ }^{5}$ Nome fictício da entrevistada.
} 
referente a sua história profissional Vaiká teve alguns empregos normalmente vinculados às atividades administrativas. Também participou do grupo EDUCOGITANS e ainda freqüenta a Terra Indígena, pois seus familiares residem lá.

\section{A cidade de Blumenau: um local onde não pode colocar material dentro do saco de arroz}

Ao chegar na cidade, o turista se depara com um discurso da cidade alemã que possui pratos típicos, cervejarias e arquitetura em enxaimel ${ }^{6}$. Em outubro tudo isto ganha grande ênfase, juntamente com trajes típicos, músicas e danças alemãs, pois neste mês é o momento da Oktoberfest.

Assim, a Oktoberfest, reeditada a cada ano é plena de citações dos mitos fundantes da história. Apagando e silenciando os conflitos, as contradições, a história pontuada pelos diversos tempos vividos, acaba por apresentar e representar uma história mitificada, apologética, seletiva, cuja versão é trazida a público através de emblemas de um passado seletivo, pelos 'fazedores de festa'. (FLORES, 1997, p.46)

As festas tradicionais, pratos típicos, mitos e demais práticas identitárias de Blumenau e região, se tratam de tradições inventadas, pois são um conjunto de práticas reguladas por regras tácitas e aceitas. (HOBSBAWN, 2008, p.10). Essas são de natureza simbólica e procuram inculcar valores e normas através da repetição, implicando em uma continuidade com o passado. Através das tradições, movimentações e demais práticas identitárias, Blumenau salienta o discurso hegemônico e homogêneo de cidade alemã, local onde se encontram as belas mulheres loiras de olhos claros, cervejas e arquitetura em enxaimel. Portanto, falar de indígenas é justamente falar do passado seletivo que Flores (1997) aponta, é um movimento diferenciado, pois a maioria das obras literárias descreve esta cidade como um local da germanidade dentro do Vale Europeu. Os mitos fundadores e as práticas identitárias que existem

\footnotetext{
${ }^{6}$ É uma técnica de construção que consiste em paredes montadas com madeira, e os espaços entre os pilares de madeira são preenchidos por tijolos ou pedras.
}

na região de Blumenau conceituam o indígena e o negro como OS DIFERENTES. Este fenômeno está presente em diferentes âmbitos: na mídia, na literatura, no imaginário social, entre outros.

Neste cenário, o indígena Xokleng/Lacklãno não se enquadra na categoria européia, e é reconhecido como não construtor de um melhor Vale do Itajaí. Ricardo Machado e André Voigt (2012, p.7) afirmam que

[...] se outrora essas diferenças foram delimitadas tão-somente por meio de determinações geográficas e biológicas, será a partir das últimas décadas do século $X X$, por outro lado, que o uso criterioso do conceito de cultura firmará as demarcações identitárias. Por isso, vivenciamos na atualidade não apenas um profundo reconhecimento da diferença cultural, mas também uma complexa valorização das identidades.

Os indígenas viviam na região do Vale Europeu antes do imigrante chegar e dominá-lo, e devido à maneira segregatória de como ocorreu à colonização pelos europeus os mesmos foram marginalizados da História Regional e Local. Porém, está História é negada oficialmente, ou mascarada por um discurso europeu branco que é oficializado todos os anos nas festas típicas que acontecem na região do Vale do Itajaí, a exemplo de Blumenau.

Na invenção desta cidade étnica, há uma profunda imbricação entre o saber sobre o que é a sociedade real e o projeto de reforma e educação do povo para tornarem-se membros de uma sociedade ficcional. Afinal, a cultura tornou-se uma mercadoria, uma mercadoria simbólica, feita de ilusão e imagem. $E$ [...] a mercadoria-cultura não é separada de seus sujeitos. O povo encarna esta mercadoria ou a mercadoria é encarnada pelo povo. (FLORES, 1997, p. 101).

Com isto, Blumenau se apresenta como a vitrine da germanidade, e normatiza um movimento que está intrínseco nos sujeitos e na cidade, e exteriorizado na relação com os visitantes e migrantes. Com efeito, o indígena e todos que não se adequam ao perfil europeu ficam as margens da cidade, e no olhar do outro como o diferente, em virtude de não fazerem parte do padrão desta vitrine. 
Os sujeitos estão em relação com a cidade e tudo que ela compõe, além deste contexto ser "[...] um território onde o homem se faz como tal, um lugar onde o sujeito vive e é vivido, já que ao mesmo tempo em que age sobre a cidade, também é afetado por ela." (HINKEL, 2013, p.43). Nesta movimentação não existe unilateralidade, pois a cidade transforma o sujeito e esse é transformado por ela, ou seja, não há passividade, por mais que a pessoa não queira, ou não goste daquele ambiente, ela é afetada. No caso de Vaiká por mais que ela não goste das pessoas de Blumenau, e observa uma hierarquização dos demais para com ela, à mesma se relaciona com a cidade e com os sujeitos que vivem nesta. Também participa da Oktoberfest, cantando e dançando músicas alemãs, além de desejar se vestir de "Frida" (forma de chamar as mulheres que usam roupas típicas alemãs durante a festa), como ela comenta em entrevista. Deste modo, ela se afeta participando da Oktoberfest fazendo parte da citada mercadoria cultural. A postura de Vaiká mostra que Blumenau não é composta apenas de pessoas brancas ou germânicas, afinal os indígenas participam dos espaços da cidade, o que inclui as festas típicas. Nesse sentido os indígenas afetam a cidade e por ela são afetados, no entanto, para pertencerem à cidade precisam incorporar de alguma forma suas práticas culturais.

Em relação à dinâmica da Oktoberfst, Flores ressalta,

[...] O marketing da festa com base nessa 'redescoberta' ou retorno às origens, apaga uma série de transformações, de inclusões e exclusões. Lidando-se com a plasticidade da cultura, sua performance atual homogeneíza os tempos, criando a aparência presente como se fosse de estruturas formais autenticamente originais, numa continuidade com o passado. (FLORES, 1997, p.36)

Esta festa autoriza o discurso normatizador da cidade e dos sujeitos que a compõem, e ao mesmo tempo reproduz a inclusão e exclusão dos grupos sociais. Isto é pautado em um passado dito comum e construído como tal em virtude de práticas tradicionais que foram alteradas e institucionalizadas para servir a novos propósitos. (HOBSBAWM, 2008, p.14).
Neste sentido, o passado em comum homogeneíza um sentimento de pertença, e se revitaliza com

[...] a memória, como propriedade de conservar certas informações, remete-nos em primeiro lugar a um conjunto de funções psíquicas, graças às quais o homem pode atualizar impressões ou informações passadas, ou que ele representa como passadas. (LE GOFF, 1992, p.423)

Com isto, acessa as lendas ou contos da região sobre um indígena que é diferente e inferior ao branco, desqualificando-o perante os demais.

Em contrapartida, o povo Xokleng/Laklãnõ sofreu um processo de genocídio desde o período de 1817 até a República Velha em 1910, porém esta última data não marca o fim dos ataques aos mesmos, pois

[...] com o propósito de defender os colonos europeus que chegavam ao sul do Brasil, dentre as diversas práticas utilizadas, cabe destaque para a contratação de bugreiros que se constituíam como grupos pagos pelo governo estadual para matar os indígenas". (KONELL, 2013, p. 27-28).

Este momento histórico foi violento para todos os envolvidos, pois o indígena se assustava com o imigrante e este teve que se adaptar no novo e diferente território.

Em se tratando deste povo, "esses eventos ocorridos em um curto espaço de tempo, fizeram com que a cultura e costumes dos indígenas Xokleng/Laklãnõ fossem modificados de forma substancial." (KONELL, 2013, p.28). Tiveram que modificar seus costumes em virtude da mudança cultural e contextual que ocorreu com a vinda do migrante, visto que "a cultura, por si só, [...] não é jamais pronta e acabada. À cada geração, é apropriada diferentemente, e modificada”. (FLORES, 1997, p.66). Está mudança foi tanto para o branco, como para indígena, pois ambos se correlacionaram, tanto no passado, como no presente. Por exemplo, a Terra Indígena Laklãnõ teve um papel importante na história de Blumenau, pois em suas terras foi construída uma barragem para proteger as cidades do Médio e Baixo Vale do Itajaí das enchentes. Conforme Konell (2013, p. 29), está construção acarretou em severas mudanças: 
[...] a construção da barragem causou violento impacto nas condições de vida dos indígenas sobreviventes dos massacres que lhes fora impetrado, considerando que ainda se adaptavam à necessidade de deixar de ser migrantes e coletores para terem de se assumir como seres em condições gregária. Com a barragem os indígenas não podiam mais viver próximo ao rio, pois quando chovia muito, ela enchia e inundava as suas casas e estragava sua plantação.

Essa construção gerou inundações que inviabilizaram o local onde essas pessoas viviam e praticavam agricultura de subsistência, e também plantavam alguns produtos para vender à comunidade não indígena. A inundação também obrigou a população a ocupar as terras mais altas que são impróprias à agricultura. Outro dado importante a esse respeito é que o povo Xokleng/ Laklãnõ era de hábito migrante, e a vida na Terra Indígena os obrigou a uma vida agrária em um grande coletivo, mas com a inundação em função da construção da barragem os mesmos ficaram separados em oito aldeias que possuem moradias distantes umas das outras, desagrupado-os. Após a construção da barragem os principais meios de subsistência foram inviabilizados, fato que levou muitos indígenas a necessidade de procurar outras formas de sobrevivência, fazendo com que muitos saiam da Terra Indígena até os dias atuais.

As intervenções ao povo originário aconteceram também por meio de atrocidades corporais, econômicas e psicológicas. Em relação a este último aspecto, é visível em olhares, discurso e postura dos brancos ditos "europeus do Vale do Itajaí". Sobre isto, Konell (2013, p.35) ressalta "a cultura indígena se apresenta na escola não indígena e também na mídia, de uma forma apenas a representar o estereótipo, sem preocupação com o respeito à diversidade no qual se desenvolve", desvalorizando o saber do povo originário perante o saber europeu do branco.

A fala autorizada do branco sobre o outro, seja negro ou indígena, está respaldada pelo sentimento de superioridade deste para com os demais desde a dita descoberta do Brasil pelos europeus. O etnocentrismo europeu permeia a história do nosso país, sendo uma construção cultural, ideológica e política repassada de geração em geração.
O etnocentrismo está calcado em sentimentos fortes como o reforço da identidade do 'eu'. Possui, no caso particular da nossa sociedade ocidental, aliados poderosos. Para uma sociedade que tem poder de vida e morte sobre muitas outras, o etnocentrismo se conjuga com a lógica do progresso, com a ideologia da conquista, com o desejo da riqueza, com a crença num estilo de vida que exclui a diferença. (ROCHA, 1994, p. 75-76).

Ou seja, ser originário é ser o passado, é viver no passado, já o branco é progresso, é futuro e tecnologia. Deste modo, o saber ancestral é também excluído e reconhecido como ultrapassado, e a ciência do branco europeu é identificada e ensinada como algo correto e que deve ser seguido. Esta premissa faz com que as pessoas tenham uma postura discriminatória em relação ao povo originário, que é exteriorizada de diversas formas, desde o olhar até as ações que sustentam o preconceito com o dito "diferente", e também uma hierarquização do branco para com os indígenas e negros.

Em relação a isto, quando é questionado sobre a cidade de Blumenau Vaiká relata,

Eu não gosto das pessoas daqui. 'Família não sei o que lá', é tudo muito 'a minha família é melhor que tua', 'a minha gente é melhor que você', 'meu cabelo loiro vale mais que o teu', 'meu olho azul tem mais prestígio que o teu', 'meu carro é melhor', 'meu bairro é melhor'. É um saco isso, até dentro da própria universidade, quem estuda de manhã, ou à noite, então eu não gosto daqui,o povo não é acoIhedor. (Entrevista com Vaiká, 2014)

A forma como Blumenau se coloca para Vaiká é excludente, o discurso e o movimento da cidade se hierarquizam perante o diferente. $O$ lugar no social que as pessoas têm para viver está interligado ao que ela possui, ao seu sobrenome e, por conseguinte, as suas origens. Como ela relata, ser loiro tem valor na cidade, os olhos azuis equivalem ao maior prestígio. $E$ através destas características, o olhar do outro se hierarquiza e qualifica ou desqualifica o sujeito.

Esta diferenciação já é vivida pela entrevistada desde a sua infância, como é possível perceber quando Vaiká relata sobre a primeira escola que frequentou em Blumenau: 
Então quando eu vim para cá, eu tinha que colocar tênis todo o dia, eu tinha que estar toda arrumadinha sempre. Fui estudar lá na Zuma, uma escola municipal lá na Velha, ficava pertinho da minha casa. Aí foi ruim porque eram todas loiras, tudo loira, os calçados delas era tudo da Abelhinha, e quem não ia de Abelhinha ia com aquelas Melissa da Xuxa de saltinho, transparente [o que era considerado moda na época]. Eu falava engraçado, não me vestia igual, o calçado era diferente, a minha bolsa era diferente, era uma bolsa, mas era diferente. $\mathrm{E}$ aí eu ficava isolada, uma criança que ficava isolada de todas, na época. (Entrevista com Vaiká, 2014)

A mudança de cidade não trouxe apenas a diferença geográfica, mas também o surgimento do branco, do diferente, e com isto uma categorização. Ao olhar para a "sandália da Xuxa ou para o cabelo loiro", Vaiká não se reconhecia como pertencente a está realidade, bem como os costumes que encontrou na nova escola. Acerca disto, ela comenta:

Mas então eu vinha falando engraçado, eu vinha para a escola de chinelo havaiana, aí eu ganhei uma mochila da minha mãe porque em Blumenau não podia colocar o material dentro do saco de arroz. Porque eu tinha que ser diferente? Para mim era natural aquilo, não tinha porque, não tinha necessidade de ser diferente. E aqui já precisava mostrar o que pra mim não tinha muito valor, entende? Aí eu tive que colocar o material em uma mochila e eu ia de tenizinho para escola todo o dia. Era um saco porque aí o verão de Blumenau é um inferno [pois é muito quente]. (Entrevista com Vaiká, 2014).

Até o momento que Vaiká foi para Blumenau, o diferente não existia, ou seja, os novos hábitos só se tornaram existentes na nova cidade. Neste momento, ela começou a se apropriar desta realidade e se transformar. Usando o tênis, mochila e deixando de lado os chinelos e o saco de arroz, ela estava escrevendo um novo ser e apreendendo o novo contexto. O que para as crianças da escola se apresentava como diferente para Vaiká era o habitual, e para ela a nova realidade era estranha.

Neste sentido das diferenças e estranhezas, em relação ao seu sotaque ela comenta: "Riam, me chamavam de indiazinha e perguntavam se a gente andava pelado. Essas coisas acabam magoando sabe. Ai você fica isolada, acuada, e a professora brigava com eles." (Entrevista com Vaiká, 2014). O imaginário das crianças era permeado do simbolismo popular e pelo discurso etnocêntrico existente no contexto de Blumenau, materializado em ações de preconceito e discriminação no cotidiano escolar, fato que faz Vaiká se sentir inferiorizada, acuada, isolada, magoada como ela menciona.

É importante frisar que a figura do povo originário na sociedade sofreu mudanças, entretanto, alguns paradigmas continuam sendo repassados e se mantém na atualidade, tanto para o branco, como para o indígena que migra para o contexto urbanizado e encontra uma realidade que o diferencia e desqualifica devido a sua cultura e etnia.

Apesar de ter ocorrido conquistas e terem aberto espaço para esses sujeitos, em Blumenau a mentalidade coletiva apela por uma história inventada para justificar uma postura germânica sobre os povos originários, portanto preconceituosa e discriminatória. Neste contexto, quando o sujeito indígena migra da Terra Indígena para Blumenau, ele se depara com uma realidade excludente que, por conseguinte, fricciona sua identidade enquanto indígena Xokleng/Laklãnõ causando-lhe um deslocamento da mesma para que está se adéque ao discurso branco/europeu.

\section{O indígena na cidade? A cor canela na cidade loira}

A cidade é um local para se viver e uma dimensão de constituição humana, uma mediação para construção da identidade e para seus objetivos, sendo assim, ela não é apenas um ambiente, construções ou ruas, é, além disto, a cidade interage com seus sujeitos e eles com ela.

Quando questionada sobre o que seus pais sonhavam para os seus filhos ela responde "o meu pai sempre idealizou que os filhos dele estudassem, conhecessem o mundo e isso e aquilo. Ele sempre falou isso para a gente." (Entrevista com Vaiká, 2014), e continua sua fala a respeito disto relatando que "[...] nesse ponto o meu pai sempre almejou isso [em referência ao sonho dele] para seus filhos, então foi por isso que nós viemos para Blumenau." (Entrevista com Vaiká, 2014). Vaiká e sua família veem na cidade um 
local para o alcance dos seus sonhos. Blumenau não se reduz a prédios, shoppings e ruas, mas se mostra como uma mediação para os sonhos do pai e, por conseguinte, os dela. Quando questionada do porque ela vive em Blumenau, sua resposta foi: "FURB" (Universidade Regional de Blumenau) e complementa "terminando [o curso de Direito], em um ano e meio, acho que é meu prazo em Blumenau." (Entrevista com Vaiká, 2014). Dentre seus sonhos, passar num concurso público e trabalhar para a causa indígena, a Universidade se torna uma mediação para alcançá-los. Tal fato faz com que Vaiká, apesar de não gostar de Blumenau, fique na cidade.

Sobre a cidade, suas relações e ambientação, ela não é compreendida como um ambiente somente material, mas uma dimensão de heterogeneidade e potencialidades enquanto local de constituição humana (HINKEL, 2013, p.42). A cidade não é um elemento estagnado ou passivo, é um agente ativo que se relaciona com os sujeitos. A exemplo, Blumenau é uma possibilidade de mediação para a construção da vida de Vaiká, principalmente pela Universidade e pela possibilidade de conseguir emprego. No entanto, a mesma cidade, também se apresenta para Vaiká com práticas excludentes para o que julga ser diferente. Através destas movimentações se constitui enquanto sujeito, com sua identidade e cosmovisão, pois é através desta que é possível caracterizar os costumes, os hábitos e crenças de um grupo social. (KONELL, 2013, p.23), e com esta movimentação vai construindo o seu futuro. A respeito dos seus sonhos Vaiká conta:

Não sei mais. Hoje eu acordei pensando, quero morar em Floripa, mas ontem eu acordei pensando quero morar em tal lugar, mas antes de ontem eu quero voltar para José Boiteux, não estou com planos, só não quero permanecer em Blumenau. Não quero advogar, se eu for advogar, teria que ser mais na área do trabalho, mas eu gostaria de passar num concurso da FUNAI e trabalhar com essa parte indígena, qualquer coisa que envolva as Terras Indígenas, não necessariamente as do povo Xokleng. Mas voltando para o sul do Brasil gostaria de permanecer na minha terra. (Grifos meus). (Entrevista com Vaiká, 2014)

Apesar de Vaiká estar se movimentando pelo contexto urbanizado e não estar morando na Terra Indígena deseja trabalhar com algo referente às suas origens. $O$ fato dela não estar na Terra Indígena não faz com que perca sua identidade indígena, mostrando, com efeito, que o estereótipo que o branco faz destes povos não é valido para ela. A identidade não está presa em um local geográfico, faz parte da subjetividade da Vaiká que está em movimento e em constante mudança. A respeito disto, Ciampa (1984. p.74) afirma "Identidade é movimento, é desenvolvimento do concreto. Identidade é metamorfose. É sermos o Um e um Outro, para que cheguemos a ser Um, numa infindável transformação", desta forma a identidade não é uma prisão, mas sim uma mediação para o ser.

Neste entrelace existencial, Vaiká é movimento, não é estática e finalizada, podendo se reinventar a todos os momentos,

[...] o sujeito só se faz sujeito nas relações com o mundo [...] A essência humana só é definida numa dialética continuada pela relação com o mundo, isto é, com as coisas, com os outros, com o corpo, com o passado e com o futuro. (RAGASSI, 1998, p.102-103).

Quando Vaiká sai da Terra Indígena e muda para Blumenau, o mundo com que se relaciona muda também e, por conseguinte, as suas relações.

E com isto, Vaiká está em constante mudança pela cidade e pelo mundo sem limite definido, e as fricções do antes e depois, do passado e do futuro se encontram no presente fazendo surgir um novo modo de Vaiká se colocar no mundo.

Considerar que cada pessoa é um 'agregado de relações sociais encarnadas num indivíduo' significa afirmar que, ao mesmo tempo há um 'eu' e não há. Não há um 'eu' originário, descolado dos outros, da realidade, enfim, do que o constitui como humano e como possibilidade de diferenciação. Não há essência, não há a priori. Por sua vez, cada pessoa concreta descola aspectos da realidade a partir do que significa como relevante, do que a emociona e mobiliza, constituindo assim modos de ser que são ao mesmo tempo sociais e singulares. (ZANELLA, 2005, p.103).

Ao falarmos de Vaiká estamos tratando de suas relações sociais, de seus sonhos, desejos, que passam pelo seu contexto, tanto da Terra Indígena, como da cidade de Blumenau, se constituindo em um entrelace de singularidades. 
Portanto, o local atual para as mediações de Vaiká é o mundo, e no caso deste artigo, o contexto urbanizado de Blumenau, que se caracteriza pela germanidade e eurocentrismo, presentes numa fricção entre brancos e indígenas. No imaginário social de Blumenau geralmente o indígena é visto como uma figura de menor valor, pois não é reconhecido como detentor de bens econômicos e pertencente ao grupo étnico de construtores do Vale do Itajaí.

A respeito do impasse branco/indígena, Vaiká relata sobre a segunda escola na qual estudou, "não falei que era índia, não falei de onde eu vim, não falei nada. E ali foi bom, não teve preconceito, não sofri nada, só a primeira semana por ser aluna nova." (Entrevista com Vaiká, 2014). Ao não afirmar a sua identidade como Xokleng perante os outros alunos, o movimento de exclusão e, por conseguinte, o preconceito já sofrido na primeira escola não é repetido e acontece somente a inclusão como igual. Portanto, neste sentindo, "a questão da identidade, assim deve ser vista não como questão apenas científica [...] é sobretudo uma questão social, uma questão política". (CIAMPA, 1997, p.127). Quando você assume uma identidade está excluindo outras possibilidades naquele breve momento, quando Vaiká assumia ser indígena na primeira escola, excluía a possibilidade de ser qualquer outra para aquelas pessoas, e ao se dizer indígena acionava um estereótipo que está imbricado no social e, por conseguinte, o preconceito e a discriminação. Deste modo, a identidade se coloca política, em virtude de toda a conotação que ela remete nos grupos e a história que ela carrega consigo. Neste caso um passado de colonizador e colonizado, que atualmente também repercute em uma hierarquia identitária, que vê o germânico como superior e positivo.

A identidade se relaciona com o contexto seja o de Blumenau ou o da Terra Indígena, e nesse entrelace Vaiká vai se constituindo e desconstituindo, criando novos modos para se colocar nos novos e velhos mundos, mas "sabemos também que as identificações, além de plurais, são dominadas pela obsessão da diferença e pela hierarquia das distinções". (SANTOS,1999. p.135). Ou seja, se existe a identificação por parte de Vaiká, existe também a diferenciação e, por conseguinte, a hierarquização. A respeito da identidade, Maheirie afirma que constituímos a identidade a partir das relações com o mundo, com as coisas, enquanto o produto das relações, a identidade é uma síntese inacabada, uma totalização destotalizada e retotalizada para se destotalizar novamente, sendo assim a identidade é histórico-dialética. (MAHEIRIE, 1994, p. 115). Esta condição de movimentação, de processo, é perceptível quando Vaiká comenta sobre suas posturas na Terra Indígena e em Blumenau, "quando estou aqui [Blumenau] eu assumo uma identidade, para eu me mesclar com a população da cidade daqui. Quando eu volto para a aldeia eu assumo uma outra identidade, até a minha fala é diferente. O jeito de falar, de se comportar" (Entrevista com Vaiká, 2014). Conforme o local Vaiká assume um modo de se colocar no mundo, portanto uma condição não exclui a outra, apesar de mudar seus modos e seus jeitos.

Ao afirmar a identidade, ao mesmo tempo em que algo é tido como igual e o outro é posto como diferente, surgindo assim uma relação de inclusão e exclusão, uma afirmação e uma negação, tornando o sujeito parte de um grupo ou não. Quando Vaiká se afirma indígena está se colocando como diferente dos brancos, da mesma forma os brancos fazem em relação a todos que não se enquadram em sua padronização. Deste modo, por identidade e o seu movimento no cenário político e hierarquizado entende-se que,

Identidade é conceito político ligado ao processo de inserção social em sociedades complexas, hierarquizadas e excludentes, bem como ao processo de inserção social nas relações internacionais. O clamor pela identidade, quer para negá-la, reforçá-la ou construí-la, é parte do confronto de poder na dialética da inclusão/exclusão e sua construção ocorre pela negação dos direitos e pela afirmação de privilégios. (SAWAIA, 2001, p. 124)

Essas diferenciações entre o olhar de si e do outro oferecem um processo de categorização entre o normal e o diferente, que pautado em um discurso germânico e excludente, impera uma relação de dominador e dominado. Por ser uma questão, tanto política como social, a

Identidade esconde negociações de sentido, choques de interesse, processos de diferenciação e hierarquização das diferenças, configurando-se como estratégia sutil de regulação das relações de poder, quer como resistência 
à dominação ou como seu reforço" (SAWAIA, 2001, p. 123).

Neste sentido, este processo de identificação está interligado com mecanismos de poder, como a normativa social de certo e errado, que regulam as relações de poder e dominação na qual a sociedade está vinculada.

Com efeito, ao ver as pessoas de Blumenau e o dito padrão de beleza hegemônico, Vaiká não se observava incluída neste padrão e se sentia inferior,

É esse contato, com o próximo, com o outro, é se sentir inferior o tempo todo, porque tua roupa não está bonita, porque teu chinelo não combina com teu cinto e você nem devia estar de chinelo, [devia estar] com sandália, com tênis, menos de chinelo, que não combina com a tua roupa toda, nem com o cabelo. Que você não usa batom, brinco ou joias, então isso foi pra mim a maior dificuldade. Acho que é por isso que criei esse estereótipo de estar sempre produzida, arrumada, eu tenho isso comigo. Não gosto que as pessoas me olhem com aquele olhar: 'ah como você está estranha hoje'. (Entrevista com Vaiká, 2014)

Já quando fala de sua estada em Florianópolis, comenta,

Senti que o povo de Blumenau é mal educado, soberbo, arrogante. É uma cidade horrível de morar, as pessoas não têm reciprocidade com ninguém, e Floripa é tudo 'zen', todo mundo ama todo mundo. Acho que é mais perigoso, tudo é mais extremo, mas você coloca um chinelo, um short, vai para o mercado,está beleza. E Blumenau não é assim. (Entrevista com Vaiká, 2014).

Quando Vaiká sai de Blumenau, ela observa como a cidade se movimenta e categoriza o diferente, fazendo assim uma hierarquização e um padrão de certo e errado. Já Florianópolis, pelo contrário, se mostra menos excludente e hierarquizada, se tornando mais acolhedora para Vaiká.

Quando Vaiká veio para Blumenau e observou as diferenças que foram produzidas pelas fricções existentes, ela se produziu a partir delas, e constituiu sua identidade presente, "[...] então, eu já vinha desenvolvendo algo para não parecer tão roceira. [...] Tinha que desenvolver algo que não demonstrasse isso, porque era o que eu era quando vim pra cá, então eu já fui desenvolvendo." (Entrevista com Vaiká, 2014). Neste caso, a cidade não tinha espaço para o jeito roceira, fazendo com que Vaiká não se sentisse pertencente à mesma, não se enquadrando no discurso germânico da cidade de Blumenau, e como uma forma de se experimentar e viver nesta cidade, ela transforma seu jeito roceiro e colono, que em Blumenau significava o passado, o errado e o ultrapassado. Ansiando por uma mudança, uma inclusão ela se recria e se transforma como uma mulher arrebatadora (termo usado por Vaiká em entrevista, 2014). Esse novo modo de se colocar no mundo, foi o que Vaiká construiu para lidar com a forma como a cidade se coloca perante ela, e como ela encara e interage com a cidade.

Já tinha desenvolvido isso, porque além de ter que me defender de alguma forma com relação ao meu comportamento e ao meu estereótipo eu nunca fui a mais bonita da sala, eu sempre fui a magrela.(Entrevista com Vaiká, 2014).

Diante da realidade de Blumenau, as características de Vaiká se mostravam diferentes, portanto ela desenvolveu uma nova forma de se vestir, de arrumar os cabelos, se maquiar e de usar acessórios, fatos que a tornaram uma mulher que começou a chamar a atenção diante dos padrões da cidade, e, por conseguinte conquista um lugar de valorização. Neste sentido Katia Maheirie (1994, p. 116-117) salienta que "o homem constrói sua identidade fazendo-se. Ao mesmo tempo que é produto, é produtor. Realiza a história ao mesmo tempo em que é realizado por ela [...]". Este não é um processo em que o sujeito é passivo, mas sim ativo e responsável.

Quando Vaiká escolhe desenvolver um novo jeito, é ativa, mudando sua história e se realizando a partir do novo contexto, criando um novo modo de ser. No jogo de ser ou não ser, de criar e recriar a sua identidade se modifica e constrói o seu "Eu" diante de Blumenau. Esse processo de criação "compreende uma série de ações e operações do sujeito, que significa, relaciona, ordena, classifica a realidade vivida transformando-a e recriando-a através da imaginação." (SCHUCMAN, 2010, p.203)

Esta mudança de contexto movimenta todo o sujeito e seus paradigmas, bem como os seus padrões. No caso de Vaiká, ela se vê como roceira 
e se transforma em arrebatadora, uma mulher bem-vestida, que usa sapatos de salto alto, joias, maquiagem e acessórios. Mas apesar disso, em certos momentos ela se posiciona como indígena, como quando teve um namorado branco. Sobre isso ela comenta:

Não [falei que era indígena] porque ai ele ia ficar rindo da minha cara, mais um que ia ficar rindo. Ai não falei. E quando fomos pra praia, eu fui pra praia com ele no carro dele, acabamos dormindo junto, da aquele romance e foi uma semana de frio, chuva, não deu praia, só ficávamos em casa namorando, na cama. Daí a gente se apaixonou, eu ficava deitada no colo dele com as pernas pra cima, durante a tarde. Pessoal assando carne, tomando cerveja. Temos 7 anos de diferença, então ele já era adulto e eu tinha 18 anos, menininha e minhas amigas eram mais novas e todos em casal. Ele ficava passando a mão no meu corpo, no meu braço, na minha perna e dizia que estava apaixonado e me amando, dizendo que eu era tão linda, falando do meu cabelo, que adorava meu cabelo. Ele não sabia como que eu tinha essa cor canela, ele não entendia, não tinha visto essa cor diferente. $\mathrm{Ai}$ falei pra ele que era de origem indígena, que meus pais moravam na aldeia, e tudo o mais. Ai ele se apaixonou mais ainda.(Entrevista com Vaiká, 2014).

Criar novas formas de se posicionar no contexto urbanizado não é apenas uma movimentação, mas uma estratégia para viver na cidade loira e é com esta movimentação que convive com a realidade excludente. Esta movimentação nada mais é que o processo de "identificações em curso" (SANTOS, 1999) em virtude de a identidade não ser algo rígido ou imutável, mas sim cheia de sentido, negociação e temporalidade. Ao mesmo tempo em que Vaiká se apropria da realidade, o seu eu está em mudança e cria novos modos para lidar com Blumenau, não deixando de ser Vaiká e sendo ela em um processo de reafirmação, reapropriação e reinvenção do seu Eu.

\section{Considerações Finais}

Para reafirmar o discurso colonizador no Vale do Itajaí, e em especial em Blumenau, são reproduzidas práticas identitárias, como músicas em alemão, língua alemã, festas e comidas típicas garantindo a manutenção do mito fundador necessário para legitimação deste discurso. Essas práticas são utilizadas como mercadoria cultural, que compõem a vitrine à ser apresentada aos turistas.

O discurso eurocêntrico presente na cidade de Blumenau não está apenas posto dentro do contexto urbanizado, ele é transmitido pelos moradores e turistas da cidade que o acessam diariamente na arquitetura, culinária, modos de viver, entre outras práticas identitárias existentes na cidade. Com efeito, o morador do Vale do Itajaí começa a reconhecer o ambiente urbanizado como o espaço de futuro, progresso, construtor e trabalhador, enquanto a Terra Indígena é desvalorizada, esquecida, atrasada e preguiçosa. Ou seja, mesmo o povo originário que não vive no contexto urbanizado, ou que o acessa esporadicamente, é visto com este olhar categorizador e excludente.

Sendo assim, no jogo da inclusão e exclusão, Vaiká vê a Terra Indígena como acolhedora, pois nela vivem seus familiares e amigos, no entanto a mesma não oferece mediações para os sonhos. Na Terra Xokleng/Laklãnõ não tem Universidade e as oportunidades de trabalho, mobilidade urbana ou estudo que ela desejava. Já Blumenau, possui um discurso eurocêntrico e excludente em relação ao indígena ou aos negros, mas apresenta mediações para o futuro desejado por Vaiká, possibilitando a Universidade, emprego e mobilidade urbana. Deste modo a Terra Indígena é vivida como um espaço acolhedor pelas pessoas que vivem lá, mas a mesma não oportuniza o que Vaiká almeja, e Blumenau dispõem de características que possibilitam a realização de seus sonhos. No entanto, as pessoas e a estrutura da cidade desqualificam o diferente através de preconceitos, estereótipos criados e reproduzidos. Este cenário paradoxal coloca para Vaiká a necessidade de criar novos modos de se posicionar.

Neste ínterim, reconhecemos três momentos de transição: "Roceira" quando veio para Blumenau e se deparou na escola onde sofreu preconceito e conviveu com o branco; "Arrebatadora" quando se reconheceu como uma mulher sensual no momento que seu namorado branco valorizou a cor canela, e a Indígena, quando ingressou na universidade e se viu enquanto uma pessoa de direitos, e posteriormente teve participação no grupo de pesquisa EDUCOGITANS. 
Apesar das três movimentações apresentadas, todas elas são Vaiká se posicionando com maior ênfase conforme o contexto, sendo assim, a identidade não é rígida nem estática, e sim se desloca e se recria diante das fricções que encontra.

Vaiká vivenciou na carne a prática excludente da cidade e como desdobramento criou novas maneiras de se colocar no mundo, seu jeito arrebatador foi uma forma de demarcar uma posição e se afirmar diante das rejeições e exclusões já vivenciadas. Do mesmo modo, projeta o seu futuro para fora de Blumenau morando em outras cidades, apesar de ver na Universidade uma forma de alcançar seu sonho, de trabalhar pelos direitos dos indígenas e ser aprovada em um concurso público.

Entretanto, antes de se transformar em uma mulher arrebatadora, ela vivenciou preconceitos, estigmas e dificuldades que o contexto urbanizado branqueador implicou e continua fazendo diariamente sobre os sujeitos que não se adéquam ao modelo eurocêntrico. Estas marcas não são tiradas facilmente desse povo que sofreu e foi violentado desde a colonização europeia na região. O movimento de exaltar a colonização, produções e cultura germânica faz um contra movimento com a cultura dos povos originários que é inferiorizada e desqualificada e, por conseguinte, os sujeitos não se veem possuidores de direitos ou de cidadania. Portanto "a cor canela na cidade loira”, expressa a movimentação do povo originário em uma cidade que apresenta o discurso da germanidade sobre o branco europeu, trabalhador, que traz o progresso, e o indígena que representa o passado e é considerado o preguiçoso. Um mito que Vaiká está desconstruindo com sua própria história, mostrando que para superar a desvalorização psicossocial o sujeito precisa vivenciar fricções e paradoxos que colocam sua identidade em constante movimento.

No entanto, quantos indígenas, que deixam as suas Terras conseguem chegar ao Ensino Superior e assim abrir as possibilidades para realizar seus sonhos? Como vivem os indígenas que migram para as cidades? Aqueles que não podem acessar a Universidade? Porque a Universidade não pode ir até a Terra Indígena? Essas são algumas reflexões que são necessárias para dar continuidade a esta pesquisa.

\section{Referências}

ARAÚJO, Ana Valéria et al. Povos Indígenas e a Lei dos "Brancos": o direito à diferença. Brasília: Ministério da Educação, Secretaria de Educação Continuada, Alfabetização e Diversidade; LACED/ Museu Nacional, 2006. 208 p. (Coleção Educação para Todos, 14) p. 23

BERTOLINO, Pedro et al. As emoções. Florianópolis: NICA Ed Independentes, 1998.

CIAMPA, Antonio da Costa. A estória do Severino e a história da Severina: Um ensaio da Psicologia Social.3ª edição. São Paulo: Editora Brasiliense, 1993.

DELGADO, Lucilia de Almeida Neves. História Oral: memória, tempo, identidades. Belo Horizonte: Autêntica, 2006

FLORES, Maria B. R. OKTOBERFEST: Turismo, Festa e Cultura na Estação do Chopp. Florianópolis: Letras Contemporâneas, 1997.

HINKEL, Jaison. Música(s), sujeito(s) e cidade(s)... Diálogo(s): O Rap em Blumenau. 2013. 147f. Tese (Doutorado em Psicologia) Universidade Federal de Santa Catarina

HOBSBAWM, Eric.; RANGER, Terence. A Invenção das Tradições. Paz e Terra: São Paulo, 2008

KONELL, Vania. Cosmovisão e educação interétnica :educação escolar indígena Xokleng/Laklãnõ , 2013. 126f. Dissertação (Mestrado em Educação) Universidade Regional de Blumenau

LANE, Silvia T. M, GODO, Wanderley (orgs). Psicologia Social: O homem em movimento. Ed. Brasiliense: São Paulo, 1984

LE GOFF, Jacques. História e Memória. 2 ed. Campinas, SP: Editora da UNICAMP, 1992.

MACHADO, Ricardo. VOIGT, André.(orgs) Desterritorializações do Vale.1 ed. Blumenau: liquidificador produtos culturais, 2012

MAHEIRIE, Katia. Agenor no Mundo: Um estudo psicossocial da identidade. Florianopolis: Letras Contemporâneas, 1994.

MARKUS, Cledes. Identidade étnica e educação escolar indígena. 2006. 156f. Dissertação (Mestrado em Educação) Universidade Regional de Blumenau, 2006.

ROCHA, Everardo P.G. O que é etnocentrismo. $6^{\text {a }}$ edição. São Paulo: Editora Brasiliense, 1984. 
SANTOS, Boaventura de Sousa.Pela mão de Alice: o social e o politico na pos-modernidade. 6.ed. - Sao Paulo: Cortez, 1999.

SAWAIA, Bader (org). As Artimanhas da Exclusão: Análise psicossocial e ética da desigualdade social. 2ed.- Petrópolis: Vozes, 2001.

SCHUCMAN, Lia V. Unificação na e pela identificação estética: construção de identidade judaica em Florianópolis/sc. IN ZANELLA, A. V. (Org.) ; MAHEIRIE, K. (Org.) . Diálogos em Psicologia Social e Arte. 1. ed. Curitiba: CRV, 2010. v. 1. P.197-211

ZANELLA, Andréa Vieira. Sujeito e alteridade: reflexões a partir da psicologia histórico-cultural. Psicol. Soc. 2005, vol.17, n.2. 